\title{
FACTORS INFLUENCING INDONESIAN MARRIED FEMALE STUDENTS PURSUING A HIGHER EDUCATION DEGREE OVERSEAS
}

\author{
Irnie Victorynie $^{1,2 *}$, Ismail Sheikh Ahmad ${ }^{1}$, Riski Munandar Hutapea ${ }^{1}$, Saddam Husein ${ }^{1}$ \\ ${ }^{1}$ International Islamic University Malaysia, Malaysia \\ ${ }^{2}$ Universitas Islam 45 Bekasi, Indonesia \\ *e-mail: victorynie@unismabekasi.ac.id
}

\begin{abstract}
Married female students face different learning experiences in higher education compared to unmarried female students. This research was conducted to determine the experiences of Indonesian married female students. The aims of this study are to identify the various factors which encourage Indonesian married female students to continue their studies, to examine the obstacles that they experience during their studies, and to identify the efforts to overcome the obstacles which are faced by the students. This research uses a qualitative approach using a case study. A total of two Indonesian married female students were interviewed. The data were analyzed using thematic analysis. Then, data from the interviews were transcribed and keywords were identified. To analyze the data, the researcher also identified the themes for further exploration. The findings showed that the factors to pursue higher education could be categorized into push factors and pull factors. The results indicate that the students not only need strength of the intention, but also need to make targets and strategies during studies, as well as to build a support system with family member, relatives, and friends to complete their studies.
\end{abstract}

Keywords: higher education, Indonesian students, married female students, pull factors, push factors.

\section{FAKTOR-FAKTOR YANG MEMENGARUHI MAHASISWA PEREMPUAN YANG MENIKAH DAN MENEMPUH PENDIDIKAN TINGGI DI LUAR NEGERI}

\begin{abstract}
Abstrak: Mahasiswi yang sudah menikah menghadapi pengalaman belajar yang berbeda di perguruan tinggi dibandingkan dengan mahasiswi yang belum menikah. Penelitian ini dilakukan untuk mengetahui pengalaman mahasiswi Indonesia yang sudah menikah. Tujuan dari penelitian ini adalah untuk mengidentifikasi berbagai faktor yang mendorong mahasiswi Indonesia yang sudah menikah untuk melanjutkan studi, mengkaji hambatan yang mereka alami selama studi, dan mengidentifikasi upaya untuk mengatasi hambatan yang dihadapi oleh siswa. Penelitian ini menggunakan pendekatan kualitatif dengan menggunakan studi kasus. Sebanyak dua mahasiswi Indonesia yang sudah menikah diwawancarai. Analisis data menggunakan analisis tematik. Kemudian, data dari wawancara disalin menjadi bentuk tulisan dan identifikasi kata kunci dilakukan. Untuk menganalisis data, peneliti juga mengidentifikasi tema untuk eksplorasi lebih lanjut. Hasil penelitian menunjukkan bahwa faktor untuk melanjutkan ke perguruan tinggi dapat dikategorikan menjadi faktor pendorong dan faktor penarik. Hasil penelitian menunjukkan bahwa mahasiswa perempuan tidak hanya membutuhkan kekuatan niat, tetapi juga perlu membuat target dan strategi selama studi, serta membangun sistem pendukung dengan anggota keluarga, kerabat, dan teman untuk menyelesaikan studi mereka.
\end{abstract}

Kata Kunci: pendidikan tinggi, mahasiswa Indonesia, mahasiswi yang sudah menikah, faktor penarik, faktor pendorong.

\section{INTRODUCTION}

Education is essential to improve the quality of human resources. The higher a person's education, the more qualified a person is. Therefore, education must continue to evolve following the needs and demands of the changing times. Recently, awareness of the importance of education is increasing which is evidenced by the increase in people striving to improve themselves by pursuing education to a higher level. Some are even willing to continue their higher education abroad in search of good schooling in neighboring countries, and other countries on various continents. Continuing to 
study abroad is not easy. Making this decision certainly needs careful consideration and involves the family. This is consistent with the opinion of Mazzarol (1998) who said that the most significant and expensive commitment ever made by students and their families is deciding to study abroad.

Everyone who decides to continue their studies abroad certainly has a reason. A number of researchers have examined the reasons or factors that influence a person in deciding to study abroad. Carlson, Burns, Useem, \& Yachimowicz (1990) explained that Canadian students assumed that investments for their future success included studying in other countries, in order to become internationally competent citizens and knowledgeable workers. Furthermore, a study focusing on American students showed that to improve their future careers, students looked for opportunities to study abroad. In addition, a study revealed the order of decision making in which students chose to study abroad in most situations: the first was the decision not to study in their home country, but abroad; next was to choose the destination country for study; and finally, the students decide on a particular institution (Mazzarol \& Soutar, 2002).

Many countries have become destinations for students to continue their studies on various continents. For example, in Asia, Malaysia is one of the countries that accepts many international students as it is one of the academic centres in Southeast Asia that offers many courses. Therefore, it is not surprising that many international students choose Malaysia as a place to study. This is in line with the statement of Mazzarol (1998), that to attract more students both locally and internationally, competition for higher education is increasing between universities and institutions of higher education. Also, a report from the Malaysian Ministry of Higher Education stated that students from around 175 countries are studying in Malaysia. International students are distributed from the southern tip of Peninsular Malaysia (Universiti Teknologi Malaysia) all the way to the northern tip (Universiti Utara Malaysia). Ofall universities in Malaysia, the largest number of international students study at the International Islamic University of Malaysia (IIUM). IIUM was built in 1983 and has accommodated students from more than 150 countries.
Based on university ranking, Malaysia has a high ranking in terms of quality of education. Malaysia also has study programs offered in each faculty. Eleven faculties have been recognized among the world's top 100, such as the Faculty of Environmental Sciences at the University of Science Malaysia, the Faculty of Agriculture at Putra Jaya University, and the Faculty of Engineering at the University of Malaya.

Also, for the largest number of international students from all over the world, Malaysian education institutions are trying to create a center of attention (Yusliza \& Shankar, 2010). Malaysia is relatively successful at attracting foreign students to continue their education there. Malaysia had an overall ranking of the 10th most competitive country in the world, based on the 2010 World Competitive book. Moreover, in the competitiveness of countries through the Overall Competitiveness Scoreboard, Malaysia ranked 57th among the world's leading economies. For Indonesian students, Malaysia is one of the countries targeted for postgraduate education. Not only men, but a number of female students are also interested in continuing their studies in Malaysia. Of course, it is very interesting that Malaysia has become one of the countries of choice for educational purposes.

There are many factors behind the desire of students to continue their studies abroad, one of which is student satisfaction. Petruzzellis \& Romanazzi (2010) underlined student satisfaction as an important factor in influencing students' decisions to choose study destination and student-specific institutions. To get satisfaction in learning, of course, you have to consider the image of the institution. This is according to the opinion of Cubillo, Sánchez, \& Cervino (2006), that what influences the decisions of international students is the image of a country, city, or institution. Furthermore, the most important factors influencing the reputation of the quality of studies at a certain institution are: the image of the institution, in terms of its reputation and the perception of quality education; its relationship or alliance with other institutions, whether or not it is familiar to the prospective students; high-quality staff; alumni base; the number of students enrolled in the institution; and whether or not the qualifications of the students are to be recognized (Maringe, 2006; Petruzzellis \& Romanazzi, 2010). 
Several other aspects must be considered in determining a country in which to study, particularly relating to the living experience in study destinations and cities, such as safety, cultural activities, international experience, university environment, facilities, quality of life, visa applications and immigration prospects (Bodycott, 2009). In the same way, building relationships and providing services to international students becomes an aspect of university assessment rather than on student facilities and income (Petruzzellis \& Romanazzi, 2010). Besides, Bodycott (2009) showed that students make decisions in determining the choice of learning destination by considering the facilities and accommodations offered and the availability of scholarships. Also, in choosing a host country in which to study, Mazzarol \& Soutar (2002) further identified six factors that influence it, namely: the knowledge and awareness of the host country, personal recommendations, cost issues, the environment, geographical proximity, and social links. From previous research results, many factors became the background for each student to continue their studies. Therefore, this study explored the factors that affect the Indonesian marriage female students in making study decisions.

In relevant research, some researchers identified various 'push' and 'pull' factors. In the same way, Mazzarol \& Soutar (2002) noted that Chinese, Indian, Indonesian, and Taiwanese students go through three stages when choosing study destination. Each stage is influenced by different 'push' and 'pull' factors. In the first stage, the 'encouragement' factor in the home country influences students' decision to study abroad. Stage two involves determining the students' area of interest for their studies and students evaluating the 'pull' factor, in the form of factors that make a person more interested. In the last stage, students choose an institution and there are other additions to the 'pull' factor, such as the reputation of the institution, the variety of courses offered, and staff expertise, which makes an institution more attractive than its competitors.

In undergoing the learning process, every student will experience challenges and obstacles. The obstacles that they face during learning, not only come from the students themselves, but also from other parties, such as from the immediate family, relatives, and friends. These parties can exert influence, both positive and negative. As stated by Mazzarol \& Soutar (2002), the main influence is personal recommendations or word of mouth references from former alumni. Even though family members, relatives, and friends influence prospective students significantly by providing information and advice, the final decision to study abroad is largely decided by the students themselves. Additionally, Mazzarol \& Soutar (2002) highlighted that undergraduate students, especially Indonesian and Taiwanese students, were strongly influenced by their parents when deciding on study destination.

Additionally, Pimpa (2003) showed that the influence of family on the Thai students differed depending on the level of education they planned to study. The majority of the research carried out at the time investigated two categories that affected families, namely 'recommendations' and 'financial support'. Then, Pimpa (2003) expanded the categories into five categories, which included finance, information, expectations, competition, and persuasion. The strongest influences among Thai students were financial influence and expectations.

In choosing higher education abroad, students are strongly influenced by their families. On the other hand, stronger relationships with their social aspects and careers motivation. In China, other factors that can significantly influence the decision for choosing higher education overseas for their children are China's one-child policy and the legacy of Confucius (Bodycott, 2009). Chinese parents want their only child to be able to gain long-term social and economic benefits in return, thus higher education abroad ensures the best for their child (Bodycott, 2009).

This research aimed to investigate the various factors that encourage Indonesian students to study abroad, especially Indonesian female students who are married. This study will also identify the obstacles that they face during their study, and to analyze the ways to solve the obstacles. This study carried out since there are still several studies missing from the previous studies. They focus only on the factors behind the eagerness of students to study abroad (Petruzzellis \& Romanazzi, 2010; Mazzarol \& Soutar, 2002; Maringe, 2006; Cubillo et al., 2006; Pimpa, 2003). They did not examine the 
obstacles that they experience during the study, also they did not investigate the solution to solve them. Furthermore, the authors used qualitative case study research method to provide the experiences of married female students during their study in detail, holistic and contextually (Merriam, 2009).

\section{METHODS}

\section{Study Design}

The research methodology is a case study using qualitative methods. This research used an exploratory case study. Yin (2008) explained that exploratory case studies are used to explore each phenomenon in the data, which serves as an attractive place for researchers. These general questions are intended to open the door for further examination of the observed phenomenon. Thus, this research method used exploration case studies in qualitative methods to understand the factors which encourage Indonesian married female students in continuing their studies abroad.

\section{Informants}

The target informants in this study were two international postgraduate students from Indonesia who were married and had children. The first informant is a Ph.D. student from the Faculty of Education at an International Islamic University in Malaysia. She is in the fourth semester. She lives in Malaysia with her husband and two children. The second informant is a Ph.D. student from the Faculty of Education at an International Islamic University in Malaysia. She is in the second semester. She lives in Malaysia with her husband and three children. The researchers chose these two students because they were both international graduate students who were married and had children. Both students are from Indonesia. The researcher wanted to investigate what factors triggered Indonesian married female students to get a higher education, what obstacles they faced during the study period, and how they overcame those obstacles. The researcher used anomaly detection to maintain the confidentiality of informants' information. Codes used for respondents were: Informant 1 , and Informant 2.

\section{Instrument}

This research employed a qualitative method using case studies as research designs and used interviews to collect data from informants (Creswell, 2005). In addition, the three research questions in this study needed answers from the informants. Therefore, the interview questions were formulated based on the research questions. This study used semi-structured interviews and applies open-ended questions for the purpose of probing. Open-ended questions allowed informants to provide a great deal of information that the authors needed through their verbal response, face, and body gesture.

The authors strived to ensure that the findings and interpretations were accurate and valid throughout the process of data collection and analysis, so that the results of the study were sound. A good qualitative study can help us to understand a situation that would otherwise be enigmatic or confusing (Eisner, 2017). Creswell (2005) said that in qualitative research, validating findings through strategies such as member checking or triangulation means the researcher can determine the accuracy or credibility of the findings.

The interviews with the informants were constructed by the authors. The conversation carried out did not occur naturally as they did not provide direct access to the experiences of the ones studied without prompts and specific questions. Interviews used when you want to learn detailed information from a few specific people are the best interview (Silverman, 1998). Thus, in this study, interviews were carried out to understand the factors which influence Indonesian married female students to pursue a higher education degree, the obstacles faced by them, and the solutions to solve the obstacles.

\section{Interview Procedure}

Interviews were conducted with two Indonesian married female students. An interview is best suited for understanding people's perceptions and experiences. The interviewer can develop the right conversation; therefore, the interviewer's role must be reflected in the results of the study. Expressing the attitude that participants' views are very valuable and useful is one of the benefits of conducting interviews (Blandford, 2013). In this study, the researcher asked semi-structured questions. While semistructured questions allow researchers to systematically interview based on the questions 
built, they also help researchers to get additional ideas and some information that is not in the list of questions that are already available. The interviews lasted about thirty minutes for each informant.

Formal procedures were followed before collecting data. Initially, the researcher sought the approval of the two Indonesian married female students to research in advance by visiting and meeting them. Then, the researcher used triangulation. In methodological triangulation, researchers collect data from documents, interviews, and observations (Denzin, 1978). Thus, for this study, the researcher interviewed the respondents through interview questions.

An important component in the data collection process is a pilot study, which is a small-scale trial of all procedures planned for use in research (Monette, Sullivan, \& DeJong, 2002). In this study, to estimate the validity of the interview questions, a trial interview was conducted on an Indonesian married female student. This student was different from the two students who became research informants. She was asked by the authors to answer eight interview questions. Every conversation was recorded by the authors. As result, there were two questions were omitted because the answers were the same as the other questions. Finally, the authors revised the interview questions before conducting the interviews.

The researcher used theme analysis to analyze data. Thematic analysis is a type of qualitative analysis (Boyatzis, 1998). This analysis was used to analyze classifications and present themes (patterns) related to data. Through interpretation, researchers can describe data in detail and relate it to a variety of subjects (Alhojailan, 2012). Also, the researcher used theme analysis to represent the level of response patterns or meanings of data related to existing research questions. Next, the data obtained from the interview was transcribed, and then keywords were identified. To begin analyzing the data, the researcher identified themes for further exploration stages. Afterward, data from the interview was transcribed on an observation sheet. Finally, all data from the interviews was combined to get all the information needed to answer the research questions.

\section{FINDINGS AND DISCUSSION Findings}

The results are presented into three sections following the authors questions. Every section presents the research dimension which are explained by the themes. The first section gives various factors that influence Indonesian married female students' decision to study abroad, especially in Malaysia. The second section describes the obstacles which are faced by the students during their studies. The third section addresses the ways to overcome the obstacles.

The authors used codes for informants to save the data from participants in the interviews, namely as Informant 1 and Informant 2 . The authors found 11 themes. Based on the findings, there are five themes for research question 1. Next, research question 2 resulted in three themes. Lastly, research question 3 contains three themes. The detailed exploration of themes can be seen in the discussion of findings.

These findings are based primarily on the analysis of interview transcripts. The findings describe all the information regarding the factors that influence Indonesian married female students' choice to study overseas. The research questions were examined together with the main ideas and the themes of the interview shown in Table 1.

Table 1. The Themes Obtained from Research Question 1

\begin{tabular}{|c|c|}
\hline $\begin{array}{l}\text { Research } \\
\text { Questions 1 }\end{array}$ & Themes \\
\hline $\begin{array}{l}\text { What are the } \\
\text { factors which } \\
\text { encourage } \\
\text { Indonesian } \\
\text { married female } \\
\text { students to study } \\
\text { abroad? }\end{array}$ & $\begin{array}{ll}\text { - } & \text { Expanding knowledge } \\
\text { - } & \text { Benefiting their country } \\
\text { - } & \text { Being close to Indonesia } \\
\text { - } & \text { Integrating knowledge } \\
& \text { (International and } \\
& \text { Islamic thought) } \\
\text { - Having diversity }\end{array}$ \\
\hline
\end{tabular}

The participating students provided explanations related to the factors that influenced them to continue their studies in Malaysia. The authors found five factors from the interviews. These factors then become the five themes of this study. 


\section{Broadening/Expanding Knowledge}

Based on the interview, the informant decided to continue her study and pursue higher education to increase her knowledge. Her intention in seeking knowledge is for investment in the world and the hereafter. Besides that, she said that the knowledge that have gained from university, will be practiced, and taught to others.

The other informant had the same reason. She continued her study because she thought that the most important factor is to seek knowledge. Seeking the knowledge for her is not a hindrance, even though she is already married and have a family.

\section{Benefiting Their Country}

The first informant clarified that the knowledge gained from her studies was certainly very useful. After the informant graduates and returns to her own country, her knowledge will benefit the community around her. The second informant also indicated that the knowledge she had obtained from campus would be useful, not only for her family but also for the surrounding community.

\section{Being Near to Indonesia}

Informant 1 took into consideration that Malaysia is a neighboring country to Indonesia. The distance between Indonesia and Malaysia is quite close. Thus, Malaysia is a suitable destination for learning.

\section{Integrating Knowledge (International and Islamic Thought)}

The first and second informants decided to study in Malaysia, specifically choosing an international standard campus with knowledge based on the Islamic view. Besides that, at International Islamic University Malaysia, there are courses that they are interested in, namely Islamization of knowledge. Both like integrated knowledge.

\section{Having Diversity}

The informants realized that on the International Islamic University Malaysia, the majority of students come from abroad. They are from different continents. Thus, the informant believes that the student body is diverse and that every international student is unique in their diversity (see Table 2).
Table 2. The Themes Obtained from Research Question 2

\section{Research Questions 2 Themes}

What are the obstacles - Time management which are faced by Indonesian married female students during - Stress management their studies?

- Priority management

Concerning the second research question, the students explained some obstacles that they faced while continuing their studies in Malaysia. Those obstacles are the themes of this research.

\section{Time Management}

Both informants claimed that they experienced obstacles in managing their time. Being a student while having a family makes it difficult for them to manage their time. Every day they are required to allocate their time appropriately. Some of the time is for campus needs, some for family needs.

\section{Stress Management}

The informants realized that another challenge in learning is self-management, specifically related to stress management. They have to think about both their studies and family matters so sometimes they become stressed and have mood swings.

\section{Priority Management}

Another obstacle experienced by informants is the struggle to manage all activities based on priorities. The informants carry out numerous types of activities because they play many different roles (Table 3). Therefore, it becomes a formidable challenge to manage their tasks and prioritize.

\section{Table 3. The Themes Obtained from Research Question 3}

\section{Research Questions 3 Themes}

How do the students $\quad$ Family support

overcome the obstacles - Intention

during their studies?

- Target and strategy 
Based on the third research question, the students explained that there are several ways to overcome the obstacles that they face during their studies. Those aspects are the themes of this research, as showed in Table 3.

\section{Family Support}

Both informants explained that to overcome obstacles while studying at university is support from the family, especially from the husband. It is truly important. The husbands will help with managing the household when the informants are on campus.

\section{Intention}

Next, the informants stated that going through the learning process requires serious intention. If the intention to learn is strong, then whatever obstacles that are encountered will be overcome. They attempt to improve/renew their intentions to finish their studies and survive. They aware that everyone has different journey in studying.

\section{Target and Strategy}

Lastly, another effort to overcome obstacles that arise during the studying process is making targets to be achieved and creating strategies to overcome the obstacles that appear during college.

\section{Discussion}

This present study has attempted to examine the factors which encourage Indonesian married female students to continue their studies, identify the obstacles which are faced by them during their studies, and explore the efforts that can be carried out to overcome the students' obstacles. For the discussion section, the researcher will only discuss the themes that are significantly and directly related to the research questions. Generally, according to the research questions, the significant findings that emerged can be categorized as follows:

\section{The Factors which Encourage Indonesian Married Female Students}

Research question 1: What are the factors which encourage Indonesian married female students to study abroad? In detail, there are five main themes for this research question which are: (1) broadening knowledge, (2) benefiting their country, (3) being near to their country of origin (Indonesia), (4) integrating knowledge (international and Islamic thought), and (5) having diversity. This can be related to previous investigations, which found that there are two categories of factors that influence international students' decisions in selecting study destinations. As explained by Mazzarol \& Soutar (2002), the two categories are: (a) push factors and (b) pull factors.

Another point of view from Jones (2017) agreed on a wide range of factors categorised according to milieus that play a role in the general international student experience. Four categorises are personal, institutional, familial and national. She also argues that all of them are pertinent and provide broader variants. Gbollie \& Gong (2020) bring another report by highlighting a significant relationship between push-pull factors and study abroad motivation. The findings claimed availability of scholarship opportunities, flexibility and perception of better education quality as important push-pull factors. Several new pull factors, including citizens' attitude and good report, development potential and hospitality and receptiveness. Meanwhile, career development and entertainment were found to be the most and least significant motivational factors.

To better understand these particular factors, Mazzarol \& Soutar (2002) added that a wide range of factors involved in the process could be categorized as factors from the home country that "push" and ones in the host country that "pull" students to study abroad. Concerning the classification of factors, Carlson et al. (1990), quoted by Buesing (2004), explained that the approach to studying travel motivation makes use of a theory that explores the push and pull factors of travel. The idea behind the theory is that people travel because they are pushed by their internal forces and pulled by the external forces or attributes of the destinations.

Furthermore, the researcher discusses details by categorizing the factors given by the informants into push and pull factors. Broadening knowledge and benefiting the country can be categorized into push factors while being near to Indonesia, integrated knowledge (international and Islamic thought) and diversity can be categorized into pull factors (see Figure 1). 


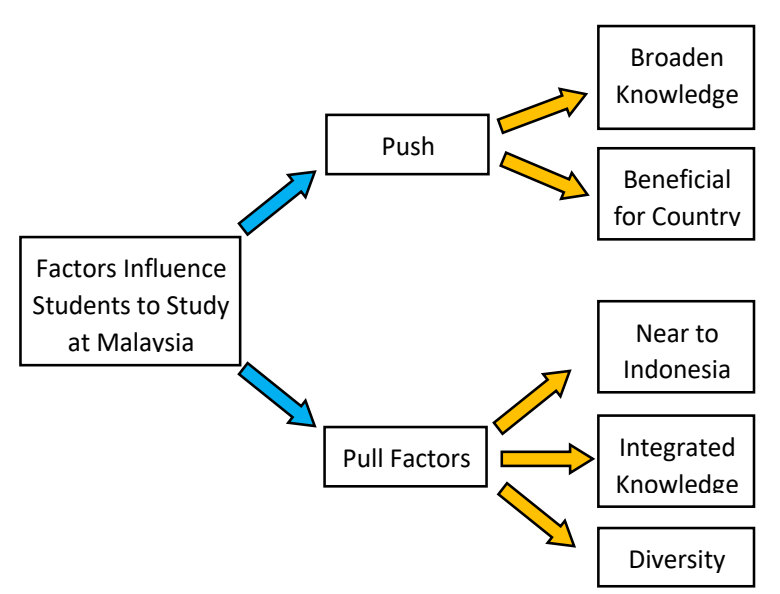

Figure 1. The Factors which Encourage to Study Abroad

\section{The Obstacles Faced by Indonesian Married Female Students during Their Studies}

Research question 2: What are the obstacles which are faced by Indonesian married female students during their studies? The findings showed that there are three main themes in relation to obstacles which are: (1) time management, (2) stress management, and (3) priority management. Concerning previous research, the majority of the research discovered that the family greatly influences to the learning process for students, at least from two categories, namely: recommendation and financial support. Then, adding those identified by Pimpa (2003), it becomes five categories, which are (a) finance, (b) information, (c) expectations, (d) competition, and (e) persuasion. Another report from Schiffeler, Stehling, Richert, \& Jeschke (2016) showed that the main obstacles to study abroad are the language barrier, the financing of the stay, and the admission to study programmes.

All obstacles experienced by Indonesian married female students that emerged in this research can be added to or supplemented by other obstacles from previous research. In addition to the three obstacles that resulted from this research, another significant factor that needs to be managed is finance. Finally, the obstacles become four kinds of management, namely time management, stress management, priority management, and financial management shown in Figure 2.

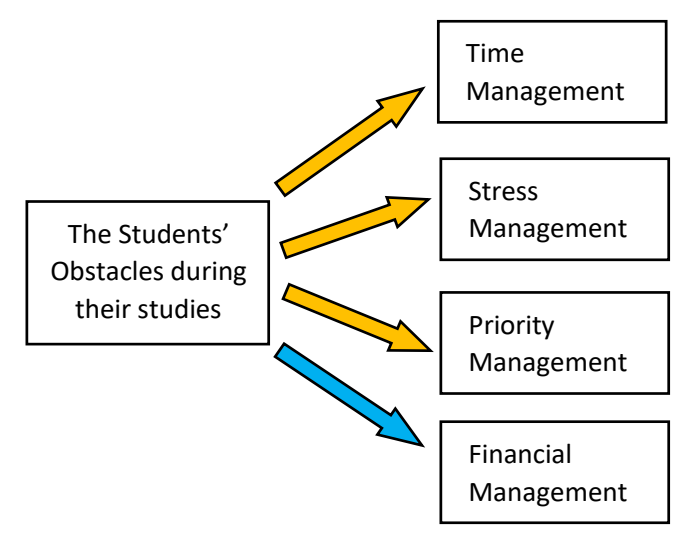

Figure 2. The Obstacles during the Study

\section{The Students Overcome the Obstacles during Their Studies}

Research question 3: How do the students overcome the obstacles during their studies? The findings for this research question resulted in three main themes which refer to: (1) support from family (husband and children), (2) intention, and (3) target and strategies. As mentioned earlier, Mazzarol \& Soutar (2002) concluded that the decision to study abroad is influenced by (a) the students themselves, (b) their (immediate) family members, and (c) relatives and friends.

Other than that, Tseng \& Newton (2002) found eight strategies for adjusting to life while studying abroad: 1) knowing self and others, 2) making friends and building relationships, 3) expanding individual worldview, 4) asking for help and handling problems, 5) establishing cultural and social contacts, 6) building relationships with advisors and instructors, 7) becoming proficient in the English language, and 8) using the tactic of letting go or knowing when to let go of a problem or concern as a stress reducer.

The efforts to overcome the obstacles that emerged in this research will be complemented by one other effort from a previous study that is quite related. In addition to the efforts to strengthen the internal self and building support from immediate family members, students also need support and assistance from relatives and friends. As a result of this discussion, the researcher obtained four efforts to overcome the problem, namely support from immediate family members, intention, targets and strategies, and support from relatives and friends shown in Figure 3. 


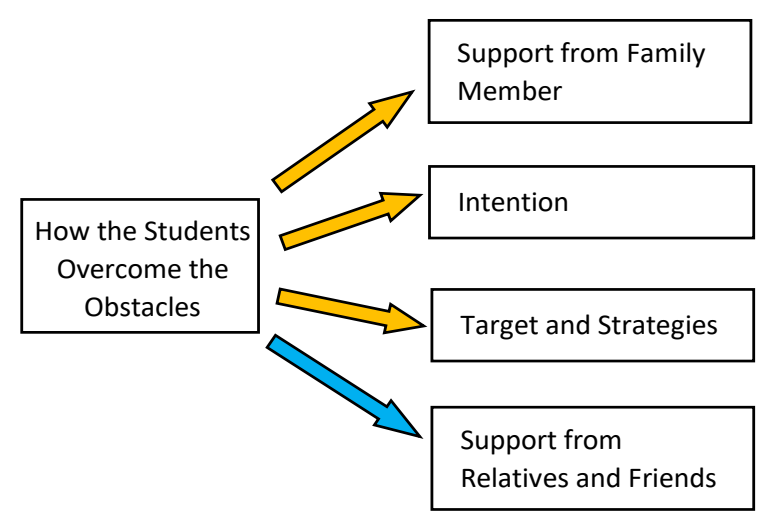

Figure 3. The Solutions to Overcome the Obstacles

\section{CONCLUSION}

From the three research questions, the researcher found that eleven themes emerged. Based on the findings, it appears that Indonesian married female students do indeed have particular factors, processes and struggles in learning during their time as postgraduate students at university. They definitely become special women with many roles both on campus and at home. At the same time, they act as students, wives, and mothers. According to the informants, five factors influence Indonesian married female students to pursue higher education in Malaysia, namely: broadening their knowledge, benefiting their country, being near to Indonesia/their home country, integrating knowledge (International and Islamic thought), and having diversity. Then, all these factors were classified into two categories: push factors and pull factors. In addition, the findings of the study revealed that there are four obstacles experienced during the learning process, namely: time management, stress management, priority management, and financial management. However, the students try to overcome these obstacles by strengthening their intention, making targets and strategies to complete their studies, and building a support system consisting of family member, relatives, and friends.

\section{REFERENCES}

Alhojailan, M. I. (2012). Thematic analysis: A critical review of its process and evaluation. West East Journal of Social Sciences, 1(1), 39-47. http://westeastinstitute.com/ journals/wp-content/uploads/2013/02/.
Blandford, A. (2013). Semi-structured qualitative studies. In M. Soegaard \& R. Dam (Eds.). The encyclopedia of human-computer interaction ( $2^{\text {nd }}$ ed). Aarhus, Denmark: The interaction design foundation. http:// www.interactiondesign.org/encyclopedia/ semi-structured_qualitative_studies.html.

Bodycott, P. (2009). Choosing a higher education study abroad destination: What mainland Chinese parents and students rate as important. Journal of Research in International Education, 8(3), 349-373. https://doi. org/10.1177/1475240909345818.

Boyatzis, R. E. (1998). Transforming qualitative information: Thematic analysis and code development. New York, NY: Sage Publications.

Buesing, W. M. (2004). Motivation for studying abroad (Masters Theses, Eastern Illinois University). https://thekeep.eiu.edu/ theses/1329.

Carlson, J. S., Burns, B. B., Useem, J., \& Yachimowicz, D. (1990). Study abroad: The experience of American undergraduates in Western Europe and the United States. New York, NY: Greenwood Press.

Creswell, J. W. (2005). Educational research: Planning, conducting and evaluating quantitative and qualitative research $\left(2^{\text {nd }}\right.$ ed). New Jersey, NJ: Pearson Merrill Prentice Hall.

Cubillo, J. M., Sánchez, J., \& Cerviño, J. (2006). International students' decision-making process. International Journal of Educational Management, 20(2), 101-115. https://doi. org/10.1108/09513540610646091.

Denzin, N. K. (1978). The research act: A theoretical introduction to sociological methods. New York, NY: McGraw-Hill.

Eisner, E. W. (2017). The enlightened eye: Qualitative inquiry and the enhancement of educational practice. New York, NY: Teachers College Press. 
Gbollie, C., \& Gong, S. (2020). Emerging destination mobility: Exploring African and Asian international students' push-pull factors and motivations to study in China. International Journal of Educational Management, 34(1), 18-34. https://doi. org/10.1108/IJEM-02-2019-0041.

Jones, E. (2017). Problematising and reimagining the notion of 'international student experience.' Studies in Higher Education, 42(5), 933-943. https://doi.org/10.1080/0 3075079.2017 .1293880 .

Maringe, F. (2006). University and course choice: Implications for positioning, recruitment and marketing. International Journal of Educational Management, 20(6), 466-479. $\quad$ https://doi. org/10.1108/09513540610683711.

Mazzarol, T. (1998). Critical success factors for international education marketing Critical success factors for international education marketing. International Journal of Educational Management, 12(4), 163-175. https://doi. org/10.1108/09513549810220623.

Mazzarol, T., \& Soutar, G. N. (2002). "Push-pull" factors influencing international student destination choice. International Journal of Educational Management, 16(2), 82-90. https://doi. org/10.1108/09513540210418403.

Merriam, S. B. (2009). Qualitative Research: A guide to design and implementation. San Francisco, CA: Jossey-Bass.

Monette, D. R., Sullivan, T. J., \& DeJong, C. R. (2002). Applied social research: Tool for the human services $\left(5^{\text {th }} \mathrm{ed}\right)$. Orlando, FL: Harcourt Press.

Petruzzellis, L., \& Romanazzi, S. (2010). Educational value: How students choose university: Evidence from an Italian university. International Journal of Educational Management, 24(2), 139-158. https://doi. org/10.1108/09513541011020954.

Pimpa, N. (2003). The influence of family on Thai students'choices ofinternationaleducation. International Journal of Educational Management, 17(5), 211-219. https://doi. org/10.1108/09513540310484931.

Schiffeler, N., Stehling, V., Richert, A., \& Jeschke, S. (2016, 14-16 November). Going to Germany to study?! Impediments from the students' perspective. Paper presented at 9th annual International Conference of Education, Research and Innovation, Seville, Spain. https://doi.org/10.21125/ iceri.2016.0563.

Silverman, D. (1998). The quality of qualitative research: The open-ended interview and its alternatives. Social Sciences in Health, 4(2), 104-118.

Tseng, W. C., \& Newton, F. B. (2002). International students' strategies for wellbeing. College Student Journal, 36(4), 597-598. https://go.gale.com/ps/anonym ous? id=GALE\%7CA96619965\&sid=goo gleScholar $\& \mathrm{v}=2.1 \& \mathrm{it}=\mathrm{r} \&$ linkaccess $=\mathrm{abs}$ $\& i s s n=01463934 \& p=A O N E \& s w=w$.

Yin, R. K. (2008). Case study research: Design and methods ( $\left.4^{\text {th }} \mathrm{ed}\right)$. Thousand Oaks, CA: Sage Publications.

Yusliza, M. Y., \& Shankar, C. (2010). Adjustment in international students in Malaysian Public University. International Journal of Innovation, Management and Technology, 1(3), 275-278. www.ijimt.org/index.php? $\mathrm{m}=$ content $\& \mathrm{c}=$ index\& $\mathrm{a}=$ show $\&$ catid $=24$ \&id $=584$. 